\title{
HUBUNGAN KECERDASAN VERBAL DAN KECERDASAN LOGIKA MATEMATIKA DENGAN KEMAMPUAN MENYELESAIKAN SOAL CERITA MATEMATIKA SISWA SD
}

\author{
Muncarno ${ }^{1)}$, Yulina ${ }^{2)}$ \\ ${ }^{1,2)}$ FKIP Universitas Lampung \\ Email: muncarno58@gmail.com
}

\begin{abstract}
This research is motivated by the low ability of grade V students of SD Negeri 8 Metro Timur in solving the math story problem. The purpose of this study is to determine the significance or not the relationship between linguistic intelligence and logicalmathematical intelligence with the ability to solve the mathematics story problem of grade $V$ students of SD Negeri 8 Metro Timur. This type of research is a correlational ex-postfacto study. Data collected by the testing techniques. The data collection instrument is a matter of multiple choice test and analysis test that has been checked for its validity and reliability. Hypothesis test results showed that there is no significant relationship between linguistic intelligence and logical-mathematical intelligence with the ability to solve the mathematics story problem of grade V students of SD Negeri 8 Metro Timur. This is caused by the existence of other factors that can affect the level of ability to solve math story problems, the intervention of variables, and the lack of maximum measuring tools prepared by researchers.
\end{abstract}

Keywords: intelligence, logical, mathematic, linguistic, story

\section{PENDAHULUAN}

Prestasi akademik siswa di Indonesia khususnya mata pelajaran matematika tergolong pada tingkat yang rendah jika dibandingkan dengan mata pelajaran lain. Hal ini dapat diketahui berdasarkan data yang diperoleh dari situs Sriwijaya Post ditulis oleh Yuliani (2014), perolehan nilai rata-rata Ujian Nasional (UN) tingkat Sekolah Dasar (SD) sederajat pada mata pelajaran matematika yakni sebesar 6,52, nilai tersebut lebih rendah jika dibandingkan dengan mata pelajaran Bahasa Indonesia dan IPA yang memperoleh nilai rata-rata sebesar 7,36 dan 7,25. Soal UN pada mata pelajaran matematika terbagi menjadi dua jenis yakni soal matematika langsung dan soal dalam bentuk cerita. Berdasarkan data dari Training Need Assessment (TNA) Pusat Pengembangan dan Pemberdayaan Pendidik dan Tenaga Kependidikan (PPPPTK) (dalam
Rahardjo dan Waluyuati, 2011: 1) ternyata soal cerita masih menjadi permasalahan untuk guru ketika mengajar dan permasalahan bagi siswa ketika mempelajari materi tersebut yang disebabkan karena sebagian dari siswa kesulitan mendapatkan informasi tentang pembelajaran soal cerita beserta contohcontohnya. Ahmad (dalam Rahardjo \& Waluyati, 2011: 14) menyatakan bahwa secara garis besar kesulitan siswa dalam menyelesaikan soal cerita yaitu kesulitan dalam memahami masalah (soal), kesulitan dalam menyusun rencana penyelesaian, kesulitan dalam menyelesaikan rencana, kesulitan dalam melihat (mengecek) kembali hasil yang telah diperoleh, dan kesulitan dalam menginterpretasikan jawaban tersebut terhadap situasi permasalahan yang terdapat dalam soal.

Berdasarkan data yang diperoleh di lapangan dengan mewawancarai wali 
kelas V A SD Negeri 8 Metro Timur pada tanggal 24 Oktober 2016, dari 29 orang dalam kelas hanya 6 orang saja yang mampu menjawab pertanyaan soal cerita matematika yang diajukan secara lisan. Artinya hanya terdapat $20,69 \%$ siswa yang mampu menjawab soal cerita matematika dengan tepat, sedangkan sebanyak 79,31\% belum mampu menjawab dengan tepat. Siswa mengalami kesulitan dalam menemukan jawaban atas pertanyaan yang diberikan oleh guru secara lisan. Berdasarkan hasil wawancara tersebut, diduga bahwa rendahnya nilai matematika pada $\mathrm{UN}$ disebabkan oleh kurangnya kemampuan siswa dalam menyelesaikan soal cerita matematika.

Soal cerita penting diberikan guru untuk melatih siswanya dalam menghadapi permasalahan sehari-hari. Soal cerita merupakan salah satu cara untuk mengasah kemampuan matematika siswa agar dapat memahami konsep dan menyelesaikan permasalahan yang dihadapinya dengan mudah. Sugondo (dalam Nafi'an, 2011: 571-572) mengemukakan bahwa soal cerita matematika merupakan soal-soal matematika yang menggunakan bahasa verbal dan berhubungan dengan kegiatan sehari-hari. Kenyataanya untuk dapat menyelesaikan soal cerita matematika tidak semudah menyelesaikan soal matematika yang sudah berbentuk bilangan matematika. Kesalahan yang sering dilakukan siswa dalam menyelesaikan soal cerita matematika adalah kurang memahami isi soal secara menyeluruh, sehingga siswa tidak memahami manakah hal-hal yang diketahui dan hal yang ditanyakan. Hudoyo \& Surawidjaja (dalam Raharjo dkk., 2009: 3) menyatakan bahwa penyelesaian soal cerita matematika hendaknya dengan membaca soal secara berulang-ulang; memahami kata demi kata, kalimat demi kalimat, identifikasikan apa yang diketahui dari masalah tersebut, identifikasikan apa yang hendak dicari, abaikan hal-hal yang tidak relevan dengan permasalahan, dan jangan menambahkan hal-hal yang tidak ada sehingga masalahnya menjadi berbeda dengan masalah yang sebenarnya dihadapi. Terdapat beberapa kemampuan yang diperlukan siswa untuk menyelesaikan soal cerita berdasarkan Pedoman Umum Matematika Sekolah Dasar (dalam Rahardjo dkk., 2009: 3), yaitu: membaca soal dan memikirkan hubungan antara bilangan-bilangan yang ada dalam soal, menuliskan kalimat matematika, menyelesaikan kalimat matematika, dan menggunakan penyelesaian untuk menjawab pertanyaan.

Pembelajaran matematika seharusnya berisi tentang permasalahanpermasalahan yang nyata adanya, yakni pembelajaran yang mengaitkan masalah dengan kehidupan sehari-hari. Menurut Rahardjo \& Waluyati (2011: 1), salah satu pembelajaran yang mengaitkan masalah dengan kehidupan sehari-hari adalah pembelajaran soal cerita matematika. Pembelajaran matematika sebagai bagian dari pendidikan formal di sekolah seharusnya dapat memberikan kontribusi dalam membangun Sumber Daya Manusia (SDM) yang berkualitas. Berdasarkan Peraturan Menteri Pendidikan Nasional (Permendiknas) Republik Indonesia (RI) nomor 22 tahun 2006 menyebutkan bahwa dalam setiap kesempatan pembelajaran matematika hendaknya dimulai dengan penggunaan masalah yang sesuai situasi.

Pendidikan ditingkat Sekolah Dasar (SD) merupakan pondasi bagi setiap siswa yang akan menentukan keberhasilannya pada jenjang pendidikan yang lebih tinggi. Kemampuan dasar yang dimiliki siswa SD seyogianya mampu mengatasi persoalan yang mungkin dialami siswa pada jenjang 
pendidikan selanjutnya. Kemampuan dasar tersebut berupa kemampuan verbal dan kemampuan logika-matematika. Melalui penelitian ini, ingin diketahui seberapa signifikan hubungan antara kecerdasan verbal dengan kemampuan menyelesaikan soal cerita matematika. Amir (2013: 4-5) menyatakan bahwa kecerdasan verbal adalah kemampuan untuk menggunakan dan mengolah katakata secara efektif baik secara lisan maupun tertulis. Ciri-ciri anak dengan kecerdasan verbal yang menonjol biasanya senang membaca, pandai bercerita, senang menulis cerita atau puisi, senang belajar bahasa asing, mempunyai perbendaharaan kata yang baik, pandai mengeja, suka menulis surat atau email, senang membicarakan ideide dengan teman-temannya, memiliki kemampuan kuat dalam mengingat nama atau fakta, menikmati permainan kata (utak-atik kata, kata-kata tersembunyi, scrabble atau teka-teki silang, bolakbalik kata, plesetan atau pantun) dan senang membaca tentang ide-ide yang menarik minatnya. Karakteristik seseorang yang memiliki kecerdasan verbal menurut Hoerr dkk. (2010: 106) yaitu pandai membaca dan menulis, menyukai dan memahami permainan kata, menyukai lelucon, menyukai tekateki, memiliki keterampilan mendengar yang baik, mudah menggabungkan bahasa deskriptif, mudah mengingat tulisan dan membicarakan informasi, menjadi pencerita yang baik, mampu menggunakan kalimat kompleks terstruktur, memahami tata bahasa dan makna bahasa, menyukai suara dan irama bahasa, suka memperdebatkan masalah atau berbicara persuasif, serta mampu menjelaskan sesuatu hal dengan baik.

Selain ingin mengetahui signifikan atau tidaknya hubungan antara kecerdasan verbal dengan kemampuan menyelesaikan soal cerita matematika, juga ingin mengetahui seberapa signifikan hubungan antara kecerdasan logika-matematika dengan kemampuan menyelesaikan soal cerita matematika. Amir (2013: 5) mengatakan bahwa seseorang dengan kecerdasan logikamatematika yang tinggi biasanya memiliki ketertarikan terhadap angkaangka, menyukai ilmu pengetahuan, mudah mengerjakan persoalan matematika, suka memecahkan misteri, senang menghitung, suka membuat perkiraan, menerka jumlah (seperti menerka jumlah uang logam dalam sebuah wadah), mudah mengingat angka-angka, menyukai permainan yang menggunakan strategi seperti catur atau games strategy, memperhatikan antara perbuatan dan akibatnya, senang menghabiskan waktu dengan mengerjakan kuis asah otak atau tekateki logika, senang menemukan cara kerja komputer, senang mengelola informasi ke dalam bentuk tabel atau grafik dan mereka mampu menggunakan komputer lebih dari sekedar bermain games. Kecerdasan logika-matematika adalah kemampuan yang berkaitan dengan penggunaan bilangan dan logika secara efektif. Siswa dengan kecerdasan logika-matematika yang tinggi memperlihatkan minat yang besar terhadap kegiatan bereksplorasi. Kecerdasan ini memiliki ciri-ciri yaitu kepekaan pada pola hubungan logis, pernyataan dan dalil, fungsi logis dan abstraksi lain. Karakteristik seseorang memiliki kecerdasan logika-matematika menurut Hoerr dkk. (2010: 138) antara lain menyukai pemberitahuan yang menggunakan angka dan pola, mampu berpikir dari hal bersifat konkret ke abstrak dengan mudah, menggunakan informasi untuk memecahkan masalah, menyukai koleksi, menikmati permainan komputer dan teka-teki, mencatat dengan teratur (dalam suatu urutan), berpikir konseptual, dapat memprediksi, dapat 
mengeksplorasi pola dan hubungan, selalu atau terus mengajukan pertanyaan, suka bereksperimen dengan berpikir logis, mampu mengorganisir pikiran, dan mampu menggunakan pendekatan yang sistematis dalam pemecahan masalah.

Berdasarkan uraian di atas, rumusan masalah pada penelitian ini adalah apakah terdapat hubungan yang signifikan antara kecerdasan verbal dan kecerdasan logika-matematika dengan kemampuan menyelesaikan soal cerita matematika siswa SD. Tujuan penelitian ini adalah untuk mengetahui signifikan atau tidaknya hubungan antara kecerdasan verbal dan kecerdasan logika-matematika dengan kemampuan menyelesaikan soal cerita matematika siswa kelas V SD Negeri 8 Metro Timur tahun pelajaran 2016/2017.

\section{METODE}

Jenis penelitian ini adalah penelitian kuantitatif, yakni menemukan pembuktian atau pengujian secara ilmiah dengan berlandaskan pada teori-teori serta hipotesis menggunakan studi expostfacto korelasional (studi korelasi).
Penelitian ini dilaksanakan di SD Negeri 8 Metro Timur dimulai dari bulan Oktober 2016 sampai bulan April 2017. Lokasi SD berada di Jalan Raya Stadion, Kelurahan Tejosari, Kecamatan Metro Timur, Kota Metro, Provinsi Lampung. Populasi dalam penelitian ini adalah semua siswa kelas V SD Negeri 8 Metro Timur berjumlah 62 orang. Teknik pengambilan sampel pada penelitian ini menggunakan sampling jenuh.

Teknik pengumpulan data menggunakan tes pilihan ganda sebagai alat ukur tingkat kecerdasan verbal $\left(\mathrm{X}_{1}\right)$ dan kecerdasan logika-matematika $\left(\mathrm{X}_{2}\right)$, sedangkan tes uraian untuk mengukur kemampuan menyelesaikan soal cerita matematika (Y). Tes pilihan ganda disertai dengan empat pilihan jawaban, jika jawaban benar bernilai 1 dan jika jawaban salah bernilai 0 . Tes yang berbentuk uraian tidak disertai pilihan jawaban, hanya saja skor diberikan setelah lembar jawaban diperiksa untuk dilihat sesuai atau tidaknya jawaban dengan indikator kemampuan menyelesaikan soal cerita sesuai rubrik penilaian berikut ini.

Tabel 1. Rubrik penilaian tes uraian soal cerita matematika

\begin{tabular}{|c|c|c|c|c|}
\hline $\begin{array}{c}\text { Tingkat } \\
\text { (level) }\end{array}$ & Kelengkapan & Pengorganisasian & $\begin{array}{c}\text { Komunikasi } \\
\text { matematis }\end{array}$ & Keterbacaan \\
\hline $\begin{array}{l}\text { A (skor } \\
4)\end{array}$ & $\begin{array}{l}\text { Mampu memahami soal cerita, } \\
\text { responden menuliskan: } \\
\text { 1. Hal-hal apa saja yang } \\
\text { diketahui } \\
\text { 2. Hal apa yang ditanyakan } \\
\text { 3. Membuat model } \\
\text { matematika } \\
\text { Mampu menyelesaikan soal cerita: } \\
\text { 1. Menentukan jawaban dari } \\
\text { model matematika } \\
\text { 2. Mengembalikan jawaban ke } \\
\text { bentuk soal }\end{array}$ & $\begin{array}{l}\text { Mampu } \\
\text { menemukan } \\
\text { masalah dengan } \\
\text { mudah }\end{array}$ & $\begin{array}{l}\text { Mampu } \\
\text { menunjukkan } \\
\text { semua cara- } \\
\text { cara yang } \\
\text { diperlukan } \\
\text { untuk } \\
\text { melakukan } \\
\text { penghitungan } \\
\text { jawaban } \\
\text { penyelesaian } \\
\text { soal cerita }\end{array}$ & $\begin{array}{l}\text { Mampu } \\
\text { menuliskan } \\
\text { atau } \\
\text { menguraikan } \\
\text { jawaban } \\
\text { dengan rapi } \\
\text { dan teratur }\end{array}$ \\
\hline $\begin{array}{l}\text { B (skor } \\
3 \text { ) }\end{array}$ & $\begin{array}{l}\text { Menuliskan hanya sebagian dari } \\
\text { pemahaman soal cerita, responden } \\
\text { menuliskan: } \\
\text { 1. Hal-hal apa saja yang } \\
\text { diketahui } \\
\text { 2. Hal apa yang ditanyakan } \\
\text { 3. Membuat model }\end{array}$ & $\begin{array}{l}\text { Sebagian masalah } \\
\text { tidak ditemukan }\end{array}$ & $\begin{array}{l}\text { Terdapat } \\
\text { pembuktian } \\
\text { jawaban, } \\
\text { namun solusi } \\
\text { yang } \\
\text { diberikan } \\
\text { tidak lengkap }\end{array}$ & $\begin{array}{l}\text { Mampu } \\
\text { menuliskan } \\
\text { atau } \\
\text { menguraikan } \\
\text { jawaban } \\
\text { secara umum }\end{array}$ \\
\hline
\end{tabular}


ISSN 2089-8703 (Print) Vol. 6, No. 3 (2017)

ISSN 2442-5419 (Online)

\begin{tabular}{|c|c|c|c|c|}
\hline $\begin{array}{c}\text { Tingkat } \\
\text { (level) }\end{array}$ & Kelengkapan & Pengorganisasian & $\begin{array}{c}\text { Komunikasi } \\
\text { matematis }\end{array}$ & Keterbacaan \\
\hline & $\begin{array}{ll} & \text { matematika } \\
\text { Mampu menyelesaikan soal cerita: } \\
\text { 1. } & \text { Menentukan jawaban dari } \\
& \text { model matematika } \\
\text { 2. } & \text { Tidak mengembalikan } \\
& \text { jawaban ke bentuk soal }\end{array}$ & & & \\
\hline $\begin{array}{c}\text { C (skor } \\
2)\end{array}$ & $\begin{array}{l}\text { Mampu menuliskan hal-hal yang } \\
\text { dapat dipahami pada soal cerita, } \\
\text { responden menuliskan: } \\
\text { 1. Hal-hal apa saja yang } \\
\text { diketahui } \\
\text { 2. Hal apa yang ditanyakan } \\
\text { 3. Membuat model } \\
\text { matematika } \\
\text { Kurang mampu menyelesaikan soal } \\
\text { cerita: } \\
\text { 1. Tidak menemukan jawaban } \\
\text { dari model matematika } \\
\text { 2. Tidak mengembalikan } \\
\text { jawaban ke bentuk soal }\end{array}$ & $\begin{array}{l}\text { Sebagian besar } \\
\text { atau hampir } \\
\text { semua masalah } \\
\text { tidak ditemukan }\end{array}$ & $\begin{array}{l}\text { Pembuktian } \\
\text { jawaban } \\
\text { kurang benar } \\
\text { atau tidak } \\
\text { tepat dan } \\
\text { solusi yang } \\
\text { diberikan } \\
\text { tidak lengkap }\end{array}$ & $\begin{array}{l}\text { Penulisan } \\
\text { jawaban } \\
\text { tidak dapat } \\
\text { diuraikan } \\
\text { secara umum }\end{array}$ \\
\hline $\begin{array}{c}\text { D (skor } \\
1)\end{array}$ & $\begin{array}{l}\text { 1. Tidak menuliskan hal-hal yang } \\
\text { seharusnya dipahami } \\
\text { 2. Tidak melaksanakan } \\
\text { penyelesaian soal cerita }\end{array}$ & $\begin{array}{l}\text { Tidak dapat } \\
\text { menemukan } \\
\text { masalah }\end{array}$ & $\begin{array}{l}\text { Tidak } \\
\text { memuat } \\
\text { jawaban atau } \\
\text { tidak ada } \\
\text { solusi yang } \\
\text { diberikan } \\
\text { dan jika ada } \\
\text { tidak } \\
\text { terdapat } \\
\text { pembuktian } \\
\text { yang kuat }\end{array}$ & $\begin{array}{l}\text { Tidak } \\
\text { terdapat } \\
\text { jawaban atau } \\
\text { jika ada } \\
\text { jawaban sulit } \\
\text { dibaca }\end{array}$ \\
\hline
\end{tabular}

Modifikasi: Hidayat (2010)

Uji validitas instrumen pada penelitian ini menggunakan teknik korelasi point biserial (untuk uji soal tes pilihan ganda) dan korelasi product moment (untuk uji soal tes uraian). Uji reliabilitas pada penelitian ini menggunakan teknik Kuder Richardson (KR) dan korelasi alpha cronbach. Uji normalitas pada penelitian ini menggunakan cara otomatis yaitu membandingkan harga normalitas dengan teknik Kolmogorov Smirnov (menggunakan aplikasi SPSS 23) yang dibandingkan dengan taraf kesalahan $5 \%(\alpha=0,05)$. Koefisien keterhubungan diperoleh melalui analisis korelasi Spearman's rank correlation coefficient yang diolah menggunakan SPSS 23.

\section{HASIL PENELITIAN DAN PEMBAHASAN \\ Hasil Penelitian}

Pengambilan data dilaksanakan pada bulan April 2017 dengan menggunakan teknik tes pilihan ganda dan tes uraian soal cerita. Berikut ini perolehan data variabel kecerdasan verbal $\left(\mathrm{X}_{1}\right)$, kecerdasan logikamatematika $\left(\mathrm{X}_{2}\right)$, dan kemampuan menyelesaikan soal cerita matematika (Y). 
ISSN 2089-8703 (Print) Vol. 6, No. 3 (2017)

ISSN 2442-5419 (Online)

Tabel 2. Distribusi frekuensi skor variabel $\mathrm{X}_{1}$

\begin{tabular}{|c|c|c|c|}
\hline No. & Nilai & $\begin{array}{c}\text { Frekuensi } \\
\text { Absolut }\end{array}$ & $\begin{array}{c}\text { Frekuensi } \\
\text { Relatif }\end{array}$ \\
\hline 1 & 3 & 2 & 3,23 \\
\hline 2 & 4 & 2 & 3,23 \\
\hline 3 & 6 & 10 & 16,13 \\
\hline 4 & 7 & 14 & 22,58 \\
\hline 5 & 8 & 19 & 30,64 \\
\hline 6 & 9 & 15 & 24,19 \\
\hline \multicolumn{2}{|c|}{ Total } & $\mathbf{6 2}$ & $\mathbf{1 0 0 , 0 0}$ \\
\hline
\end{tabular}

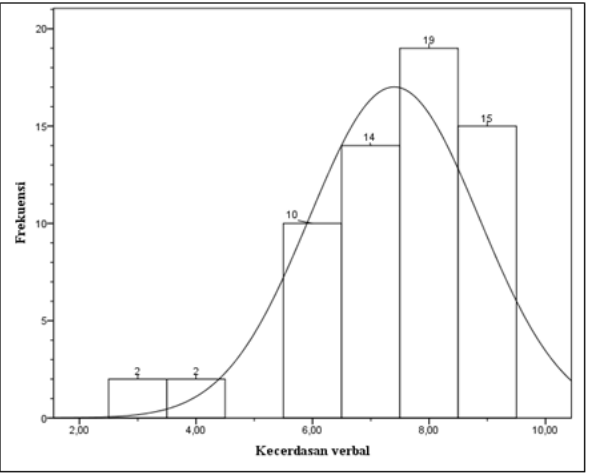

Gambar 1. Histogram distribusi skor variabel $\mathrm{X}_{1}$.

Tabel 3. Distribusi frekuensi skor variabel $\mathrm{X}_{2}$

\begin{tabular}{|c|c|c|c|}
\hline No. & Nilai & $\begin{array}{c}\text { Frekuensi } \\
\text { Absolut }\end{array}$ & $\begin{array}{c}\text { Frekuensi } \\
\text { Relatif }\end{array}$ \\
\hline 1 & 3 & 1 & 1,61 \\
\hline 2 & 4 & 1 & 1,61 \\
\hline 3 & 5 & 1 & 1,61 \\
\hline 4 & 6 & 6 & 9,68 \\
\hline 5 & 7 & 18 & 29,03 \\
\hline 6 & 8 & 35 & 56,45 \\
\hline \multicolumn{2}{|c|}{ Total } & $\mathbf{6 2}$ & $\mathbf{9 9 , 9 9}$ \\
\hline
\end{tabular}

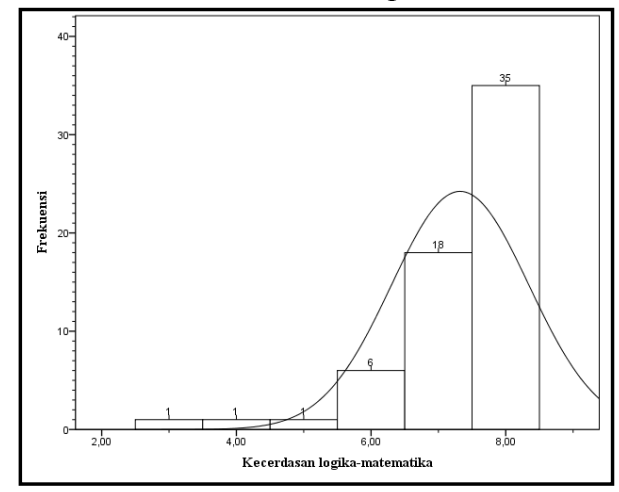

Gambar 2. Histogram distribusi skor variabel $\mathrm{X}_{2}$.

Tabel 4. Distribusi frekuensi skor variabel $\mathrm{Y}$

\begin{tabular}{|c|c|c|c|}
\hline No. & Nilai & $\begin{array}{c}\text { Frekuensi } \\
\text { Absolut }\end{array}$ & $\begin{array}{c}\text { Frekuensi } \\
\text { Relatif }\end{array}$ \\
\hline 1 & 3 & 2 & 3,23 \\
\hline 2 & 4 & 2 & 3,23 \\
\hline 3 & 5 & 1 & 1,61 \\
\hline 4 & 8 & 1 & 1,61 \\
\hline 5 & 10 & 41 & 66,13 \\
\hline 6 & 12 & 2 & 3,23 \\
\hline 7 & 14 & 1 & 1,61 \\
\hline 8 & 21 & 4 & 6,45 \\
\hline 9 & 22 & 4 & 6,45 \\
\hline 10 & 27 & 1 & 1,61 \\
\hline 11 & 28 & 2 & 3,23 \\
\hline 12 & 34 & 1 & 1,61 \\
\hline \multicolumn{2}{|c|}{ Total } & $\mathbf{6 2}$ & $\mathbf{1 0 0 , 0 0}$ \\
\hline
\end{tabular}

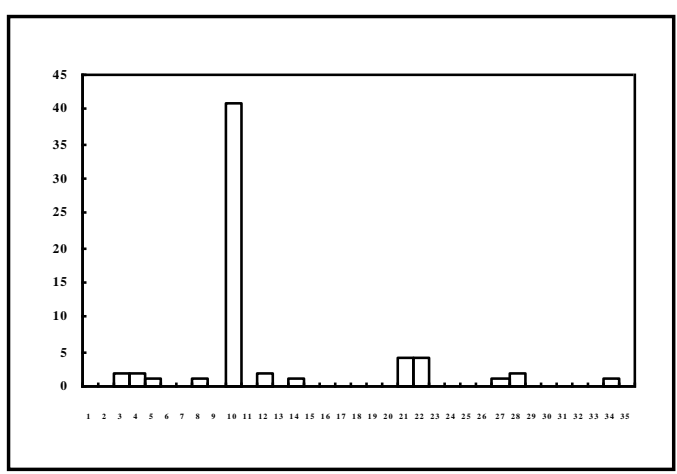

Gambar 3. Histogram distribusi skor variabel Y.
Penentuan tingkat kecerdasan verbal, kecerdasan logika-matematika, dan kemampuan menyelesaikan soal cerita matematika dilakukan melalui penghitungan dan pembagian data menjadi tiga bagian yakni tinggi, sedang, dan rendah. Berikut ini penentuan distribusi frekuensi untuk mengetahui tinggi rendahnya kecerdasan maupun 
ISSN 2089-8703 (Print) Vol. 6, No. 3 (2017)

ISSN 2442-5419 (Online)

kemampuan responden dalam menyelesaikan instrumen penelitian.

Tabel 5. Penentuan distribusi frekuensi tingkat varabel $\mathrm{X}_{1}, \mathrm{X}_{2}$, dan $\mathrm{Y}$

\begin{tabular}{|c|c|}
\hline Ketentuan Batasan & Kategori \\
\hline Skor $>(2 / 3 \times$ skor maksimal $)$ & Tinggi \\
\hline$(1 / 3 \times$ skor maksimal $)<$ Skor $\leq(2 / 3 \times$ skor maksimal $)$ & Sedang \\
\hline Skor $\leq(1 / 3 \times$ skor maksimal $)$ & Rendah \\
\hline
\end{tabular}

Tabel 6. Daftar distribusi frekuensi tingkat variabel $\mathrm{X}_{1}, \mathrm{X}_{2}$, dan $\mathrm{Y}$

\begin{tabular}{|c|c|c|c|c|}
\hline $\begin{array}{c}\text { Variabel } \\
\text { Penelitian }\end{array}$ & Pembagian Skor & Frekuensi & Persentase & Kategori \\
\hline \multirow{3}{*}{$\begin{array}{c}\text { Kecerdasan } \\
\text { verbal }\left(\mathrm{X}_{1}\right)\end{array}$} & skor $>6$ & 48 & 77,42 & Tinggi \\
\cline { 2 - 5 } & $3<$ skor $\leq 6$ & 12 & 19,35 & Sedang \\
\cline { 2 - 5 } & skor $\leq 3$ & 2 & 3,22 & Rendah \\
\cline { 2 - 5 } & Jumlah & 62 & 99,99 & \\
\hline $\begin{array}{c}\text { Kecerdasan } \\
\text { logika- } \\
\text { matematika }\end{array}$ & skor $>5,33$ & 59 & 95,16 & Tinggi \\
\cline { 2 - 5 }$\left(\mathrm{X}_{2}\right)$ & $2,67<$ skor $\leq 5,33$ & 3 & 4,84 & Sedang \\
\cline { 2 - 5 } & skor $\leq 2,67$ & 0 & 0 & Rendah \\
\cline { 2 - 5 } $\begin{array}{c}\text { Kemampuan } \\
\text { menyelesaikan } \\
\text { soal cerita } \\
\text { matematika (Y) }\end{array}$ & Jumlah & 62 & 100,00 & \\
\cline { 2 - 5 } & $13,33<$ skor $\leq 26,67$ & 9 & 6,45 & Tinggi \\
\cline { 2 - 5 } & skor $\leq 13,33$ & 49 & 79,52 & Sedang \\
\hline \multirow{2}{*}{ Jumlah } & 62 & 100 & Rendah \\
\hline
\end{tabular}

Uji normalitas data variabel $\mathrm{X}_{1}$, $\mathrm{X}_{2}$, dan $\mathrm{Y}$ dilakukan menggunakan perhitungan Kolmogorov Smirnov dengan kaidah pengambilan keputusan jika nilai Sig. > 0,05 maka data berdistribusi normal, sedangkan jika nilai Sig. < 0,05 maka data tidak berdistribusi normal. Berikut ini rekapitulasi hasil uji normalitas menggunakan SPSS 23.

Tabel 7. Rekapitulasi uji normalitas variabel $\mathrm{X}_{1}, \mathrm{X}_{2}$, dan $\mathrm{Y}$

\begin{tabular}{|c|c|c|c|c|}
\hline Variabel & $\begin{array}{c}\text { Derajat } \\
\text { kebebasan } \\
(\mathbf{d k})\end{array}$ & Nilai Sig. & $\begin{array}{c}\text { Taraf } \\
\text { kesalahan 5\% } \\
(\boldsymbol{\alpha}=\mathbf{0 , 0 5})\end{array}$ & Status \\
\hline $\mathrm{X}_{1}$ & 62 & 0,00 & 0,05 & $\begin{array}{c}\text { Data tidak berdistribusi } \\
\text { normal }\end{array}$ \\
\hline $\mathrm{X}_{2}$ & 62 & 0,00 & 0,05 & $\begin{array}{c}\text { Data tidak berdistribusi } \\
\text { normal }\end{array}$ \\
\hline $\mathrm{Y}$ & 62 & 0,00 & 0,05 & $\begin{array}{c}\text { Data tidak berdistribusi } \\
\text { normal }\end{array}$ \\
\hline
\end{tabular}

Uji korelasi sederhana menggunakan teknik uji Spearman's rank correlation coefficient dengan kaidah pengambilan keputusan jika nilai signifikansi lebih kecil dari taraf signifikansi maka hubungan tersebut signifikan, sedangkan jika nilai signifikansi lebih besar dari taraf signifikansi maka hubungan tersebut tidak signifikan. Berikut ini hasil uji korelasi sederhana antarvariabel. 
ISSN 2089-8703 (Print) Vol. 6, No. 3 (2017)

ISSN 2442-5419 (Online)

Tabel 8. Hasil uji korelasi sederhana antar-variabel

\begin{tabular}{|c|c|c|c|c|}
\hline $\begin{array}{c}\text { Variabel } \\
\text { Penelitian }\end{array}$ & & $\begin{array}{c}\text { Kecerdasan } \\
\text { verbal }\left(\mathbf{X}_{1}\right)\end{array}$ & $\begin{array}{c}\text { Kecerdasan } \\
\text { logika- } \\
\text { matematika }\left(X_{2}\right)\end{array}$ & $\begin{array}{c}\text { Kemampuan } \\
\text { menyelesaikan } \\
\text { soal cerita } \\
\text { matematika }(\mathbf{Y})\end{array}$ \\
\hline \multirow{5}{*}{$\begin{array}{c}\text { Kecerdasan } \\
\text { verbal }\left(\mathbf{X}_{1}\right)\end{array}$} & Nilai Koefisien & & 0,47 & 0,10 \\
\hline & Tingkat hubungan & & Sedang & Sangat rendah \\
\hline & Nilai signifikansi & & 0,00 & 0,46 \\
\hline & Taraf signifikansi & & $0,05(5 \%)$ & $0,05(5 \%)$ \\
\hline & Status & & Signifikan & Tidak signifikan \\
\hline \multirow{5}{*}{$\begin{array}{c}\text { Kecerdasan } \\
\text { logika- } \\
\text { matematika } \\
\left(\mathbf{X}_{2}\right)\end{array}$} & Nilai Koefisien & 0,47 & & 0,08 \\
\hline & Tingkat hubungan & Sedang & & Sangat rendah \\
\hline & Nilai signifikansi & 0,00 & & 0,52 \\
\hline & Taraf signifikansi & $0,05(5 \%)$ & & $0,05(5 \%)$ \\
\hline & Status & Signifikan & & Tidak signifikan \\
\hline \multirow{5}{*}{$\begin{array}{c}\text { Kemampuan } \\
\text { menyelesaikan } \\
\text { soal cerita } \\
\text { matematika }(Y)\end{array}$} & Nilai Koefisien & 0,10 & 0,08 & \\
\hline & Tingkat hubungan & Sangat rendah & Sangat rendah & \\
\hline & Nilai signifikansi & 0,46 & 0,52 & \\
\hline & Taraf signifikansi & $0,05(5 \%)$ & $0,05(5 \%)$ & \\
\hline & Status & Tidak signifikan & Tidak signifikan & \\
\hline
\end{tabular}

Uji korelasi ganda antara variabel $\mathrm{X}_{1}$ dan $\mathrm{X}_{2}$ bersama-sama dengan variabel $\mathrm{Y}$ pada penelitian ini adalah untuk menentukan nilai $\mathrm{F}$ hitung $\left(\mathrm{F}_{\mathrm{h}}\right)$ yang kemudian dikonsultasikan dengan nilai $F$ tabel $\left(F_{t}\right)$ secara manual. Nilai $F$ tabel pada penelitian ini yaitu sebesar $3,15\left(\mathrm{~F}_{\mathrm{t}}=3,15\right)$. Kaidah pengambilan keputusan korelasi ganda pada penelitian ini adalah jika nilai $F_{h}$ lebih kecil dari $F_{t}$ maka hubungan tersebut tidak signifikan, sedangkan jika $F_{h}$ lebih besar dari $F_{t}$ maka hubungan tersebut signifikan. Berikut ini hasil uji korelasi ganda antara variabel $X_{1}$ dan $X_{2}$ bersama-sama dengan variabel $Y$.

Tabel 9. Hasil uji korelasi ganda variabel $X_{1}$ dan $X_{2}$ dengan variabel $Y$

\begin{tabular}{|l|c|c|c|c|c|}
\hline \multicolumn{1}{|c|}{ Variabel } & $\begin{array}{c}\text { Koefi } \\
\text { sien }\end{array}$ & $\begin{array}{c}\text { Tingkat } \\
\text { hubungan }\end{array}$ & F hitung & F tabel & Status \\
\hline $\begin{array}{l}\text { Kecerdasan verbal dan logika- } \\
\text { matematika dengan } \\
\text { kemampuan menyelesaikan } \\
\text { soal cerita matematika }\end{array}$ & 0,11 & $\begin{array}{l}\text { Sangat } \\
\text { rendah }\end{array}$ & 0,36 & 3,15 & $\begin{array}{c}\text { Tidak } \\
\text { signifik } \\
\text { an }\end{array}$ \\
\hline
\end{tabular}

\section{Pembahasan}

Berdasarkan hasil pengujian korelasi ganda antara variabel kecerdasan verbal dan kecerdasan logika-matematika secara bersama-sama terhadap variabel kemampuan menyelesaikan soal cerita matematika termasuk dalam tingkat hubungan sangat rendah dan tingkat kebermaknaan hubungan tersebut tidak signifikan. Rendahnya hubungan antar-variabel yang diteliti memberikan arti bahwa tingkat kemampuan menyelesaikan soal cerita matematika siswa kelas V SD Negeri 8 Metro Timur tidaklah bergantung pada tinggi atau rendahnya tingkat kecerdasan verbal maupun kecerdasan logika-matematika siswa.

Terdapat banyak faktor yang dapat mempengaruhi tinggi rendahnya kemampuan siswa dalam menyelesaikan soal cerita matematika selain dari kecerdasan verbal dan logikamatematikanya. Purwanto (dalam Bahri, 
2015: 12) menyebutkan faktor-faktor yang dapat mempengaruhi kemampuan siswa, termasuk kemampuan menyelesaikan soal cerita matematika antara lain sebagai berikut. (1) Faktor yang ada pada diri individu, seperti kematangan, kecerdasan, latihan motivasi, dan faktor pribadi. (2) Faktor yang ada di luar individu, meliputi faktor lingkungan keluarga/keadaan rumah tangga, guru dan cara mengajar, alat-alat yang dipergunakan dalam belajar mengajar, lingkungan dan kesempatan yang tersedia, dan motivasi sosial.

$\begin{array}{cl}\begin{array}{c}\text { Kecerdasan } \\ \text { verbal maupun } \\ \text { kecerdasan }\end{array} & \text { logika-matematika }\end{array}$
merupakan sebagian kecilnya saja dari faktor-faktor yang dapat mempengaruhi kemampuan menyelesaikan soal cerita matematika siswa. Berdasarkan pendapat Purwanto di atas, unsur kecerdasan merupakan salah satu faktor yang mempengaruhi kemampuan seseorang jika ditinjau dari segi internal, masih ada unsur kematangan seseorang, motivasi untuk berlatih, dan dari faktor kepribadian beserta faktor eksternal seseorang yang dapat mempengaruhi kemampuan tersebut. Masih terdapat faktor lain yang dapat mempengaruhi kemampuan seseorang dalam menyelesaikan masalah, Stendall (dalam Tambychik \& Meerah, 2010: 147) menyatakan bahwa perlunya konsentrasi yang baik, dapat menangkap persepsi yang tepat, mampu berpikir dengan logis dan mampu mengingat secara efektif merupakan faktor penting yang diperlukan oleh siswa dalam belajar menyelesaikan masalah.

Faktor lain yang dapat mempengaruhi seseorang dalam menyelesaikan soal cerita menurut Schoenfeld (dalam Guven \& Cabackor, 2013: 131) antara lain: resources, heuristics, control, dan belief system. Adapun yang dimaksud dengan Resources menurut Schoenfeld yaitu pengetahuan formal dan informal tentang fakta dan rutinitas, heuristics yaitu aturan praktis untuk membuat kemajuan dalam masalah yang tidak biasa, control yaitu pengetahuan metakognitif tentang bagaimana memilih resources dan heuristics, sedangkan belief system yaitu pandangan pada dunia siswa, termasuk persepsi diri siswa.

Faktor lain yang dapat mempengaruhi kemampuan seseorang namun faktor tersebut tidak dapat dikur atau diamati seperti faktor lingkungan keluarga, guru dan cara mengajarnya. Hal ini dinamakan dengan adanya intervensi variabel, peneliti tidak dapat menjangkau kondisi latar belakang keluarga siswa maupun cara mengajar guru tentang materi pemecahan soal cerita matematika dalam bentuk angka kuantitatif.

Alat ukur yang digunakan pada penelitian ini kurang sempurna, meskipun pada pengujian validitas dan reliabilitas instrumen menunjukkan hasil yang valid dan reliabel namun masih dirasa kurang maksimal dalam menyusun butir-butir instrumen penelitian. Hal ini baru dapat disadari ketika dilakukan uji prasyarat analisis data yang menunjukkan bahwa data tidak berdistribusi normal. Instrumen yang baik dan dapat dipercaya apabila hasil data yang diperoleh menunjukkan data yang berdistribusi secara normal dengan pembagian tingkat kesukaran yang sesuai antara mudah, sedang, hingga yang sulit untuk dikerjakan oleh objek penelitian. Selain alat ukur yang kurang maksimal, juga diperlukan jumlah sampel yang lebih besar dari jumlah yang diteliti pada penelitian ini.

\section{KESIMPULAN DAN SARAN}

Berdasarkan analisis data dan pembahasan hasil penelitian, maka diperoleh simpulan bahwa tidak terdapat 
hubungan yang signifikan antara kecerdasan verbal dan kecerdasan logika-matematika secara bersama-sama terhadap kemampuan menyelesaikan soal cerita matematika siswa kelas V SD Negeri 8 Metro Timur tahun pelajaran 2016/2017. Hal ini dapat diketahui berdasarkan hasil uji koefisien korelasi ganda yang memperoleh nilai sebesar 0,11 , hal ini berarti tingkat hubungan antara variabel $\mathrm{X}_{1}$ dan $\mathrm{X}_{2}$ terhadap variabel $\mathrm{Y}$ dalam kategori sangat rendah. Hasil uji signifikansi diperoleh nilai sebesar 0,36 lebih kecil dari nilai $\mathrm{F}$ tabel $(\mathrm{Ft}=3,15)(0,36<3,15)$ yang berarti bahwa hubungan antara variabel $x 1$ dan x2 terhadap variabel y tidak signifikan. Hal ini menunjukkan bahwa kecerdasan verbal dan kecerdasan logikamatematika secara bersama-sama memiliki pengaruh yang sangat rendah dan tidak signifikan terhadap kemampuan menyelesaikan soal cerita matematika siswa kelas V SD Negeri 8 Metro Timur tahun pelajaran 2016/2017. Tidak signifikannya hubungan tersebut dikarenakan perolehan nilai koefisien korelasi antara variabel bebas secara bersama-sama dengan variabel terikat disebabkan karena adanya faktor lain yang lebih mempengaruhi tingkat variabel kemampuan menyelesaikan soal cerita matematika, adanya intervensi variabel, dan kurang maksimalnya alat ukur yang disusun.

Saran dari penelitian ini guna perbaikan dan peningkatan dalam dunia pendidikan di Indonesia khususnya di SD Negeri 8 Metro Timur. Adapun pihak yang dimaksud antara lain sebagai berikut. (1) Siswa, diharapkan dapat lebih rajin untuk berlatih menyelesaikan soal-soal matematika dalam bentuk cerita dan siswa diharapkan dapat lebih memahami prosedur penyelesaian soal cerita matematika yang baik dan benar. (2) Guru, diharapkan untuk lebih banyak memberikan soal-soal matematika dalam bentuk cerita terhadap ssiswa dan memberikan penekanan kepada siswa untuk melaksanakan penyelesaian soal cerita matematika sesuai dengan prosedur yang baik dan benar. (3) Pengelola sekolah, diharapkan dapat meningkatkan sarana dan prasarana di SD Negeri 8 Metro Timur. Perlunya penambahan media-media pembelajaran di kelas untuk membantu guru dalam menyampaikan materi-materi pembelajaran yang berkaitan dengan kecerdasan verbal dan kecerdasan logika-matematika serta pembelajaran soal cerita matematika. (4) Peneliti lanjutan, Kepada peneliti lanjutan diharapkan untuk dapat mengembangkan variabel penelitian yang lebih variatif, memperluas populasi penelitian, dan mengembangkan instrumen penelitian yang lebih bervariasi lagi.

\section{DAFTAR PUSTAKA}

Amir, A. 2013. Pembelajaran matematika dengan menggunakan kecerdasan majemuk (multiple intelligences). Logaritma. Vol.1, No.01: 1-14.

Bahri, Moh. 2015. Peningkatan Kemampuan Menyelesaikan Soal Cerita Matematika Materi Menghitung Keliling Persegi dan Persegi Panjang Menggunakan Media Kartu Kerja pada Siswa Kelas III MI Miftahul Hidayah Pakong Pamekasan. (Skripsi). 12 November 2015. Digital library UIN Sunan Ampel. 12 November 2015 http://digilib.uinsby.ac.id/2649/. Diakses pada 9 Juni 2017.

Guven, B., \& Cabakcor, B. O. 2013. Factors Influencing Mathematical Problem-Solving Achievement of Seventh Grade Turkish Students. 
ISSN 2089-8703 (Print) Vol. 6, No. 3 (2017)

ISSN 2442-5419 (Online)

Learning and Individual Differences: 131-137.

Hidayat, M. Menilai Penyelesaian Soal Cerita dengan Kriteria Penilaian (RUBRIK). 19 Oktober 2010 https://makmunhidayat.wordpres s.com /2010/10/19/menilaipenyelesaian-soal-cerita-dengankriteria-penilaian-rubrik/.

Diakses pada 8 Maret 2017.

Hoerr, T. R., Boggeman, S., \& Wallach, C. 2010. Celebrating Every Learner: Activities and Strategies for Creating a Multiple Intelligences Classroom. United States: Jossey-Bass.

Nafi'an, M. I. 2011. Kemampuan siswa dalam menyelesaikan soal cerita ditinjau dari gender di sekolah dasar. Seminar Nasional Matematika dan Pendidikan Matematika. 571-577.

Raharjo, M., Ekawati, E., \& Rudianto, Y. 2009. Pembelajaran Soal Cerita di SD. D. I. Yogyakarta: Pusat Pengembangan

Peningkatan dan Pemberdayaan Pendidik dan Tenaga Kependidikan (PPPPTK) Matematika.

Rahardjo, M., \& Waluyati, A. 2011. Pembelajaran Soal Cerita Operasi Hitung Campuran di Sekolah Dasar. Yogyakarta: Kementrian Pendidikan Nasional.

Tambychik, T., \& Meerah, T. S. M., 2010. Students' Difficulties in Mathematics Problem-Solving: What Do They Say?. Procedia Social and Behavioral Sciences. International conference on
Mathematics Education Research 2010: 143-151.

Yuliani. Nilai Matematika Terendah. Sriwijaya Post. Soegeng Haryadi (ed). $\quad 20 \quad$ Juni 2014 http://palembang.tribunnews.com /2014/06/20/nilai-matematikaterendah. Diakses pada 8 Januari 2017. 